\title{
Molecular variability of Merremia mosaic virus infecting tomatoes in Venezuela
}

\author{
Gustavo Romay $^{1}$ - Francis Geraud-Pouey ${ }^{2}$ - Dorys T. Chirinos ${ }^{2} \cdot$ Iván Galindo-Castro ${ }^{1}$. \\ María A. Franco ${ }^{1}$
}

Received: 25 October 2015 / Accepted: 5 April 2016/Published online: 9 April 2016

(C) Australasian Plant Pathology Society Inc. 2016

\begin{abstract}
Merremia mosaic virus (MeMV) is a relative frequent begomovirus infecting tomato fields in Venezuela. However, its genetic variability remains unclear. In this study, $20 \mathrm{MeMV}$ infected tomato plants, collected from different Venezuelan states, were selected to estimate the genetic variations by partial genome sequencing of the common region and part of the genes AV1 and AC1, comprising $1012 \mathrm{bp}$. Nucleotide sequence identity among Venezuelan isolates ranged between 91.4 and $100 \%$, suggesting a high genetic variability when compared with other Latin American isolates from Puerto Rico, Belize, and Saint Kitts and Nevis. Phylogenetic analysis showed two main clusters. The cluster 1 included isolates from Central America and Venezuela, while the cluster 2 included only isolates from Venezuela.
\end{abstract}

Keywords Begomovirus · Genetic diversity $\cdot$ Phylogenetic analyses · Tomato crops

Begomoviruses are recognized as one of the main virus groups causing tremendous economic losses to tomato producers worldwide. In Venezuela, severe begomoviral outbreaks have been reported in tomatoes and other crops (Chirinos and Geraud-Pouey 2011; Romay et al. 2010, 2014). Recently, Merremia mosaic virus (MeMV) was found

Gustavo Romay

gromay@gmail.com

1 Fundación Instituto de Estudios Avanzados (IDEA), Carretera Nacional Hoyo de la Puerta-Baruta, Sartenejas, Caracas 1080, Venezuela

2 La Universidad del Zulia (LUZ), Facultad de Agronomía, Unidad Técnica Fitosanitaria, Maracaibo 4005, Estado Zulia, Venezuela as one of the three more prevalent begomoviruses in Venezuelan tomato fields (Geraud-Pouey et al. 2015). It was first reported infecting Merremia quinquefolia. (Convolvulaceae) in Puerto Rico (Brown et al. 2001) and, afterwards, was reported in Belize (GenBank accession numbers for DNA-A components: EU709521; EU709522; EU709525), Saint Kitts and Nevis, (GenBank accession number for DNA-A component: GU320575) and Venezuela (GenBank accession number for DNA-A component: AY50899). In the latter case, the virus was found infecting tomatoes and named "tomato mosaic leaf curl virus" (Nava et al. 2006). However, this isolate is currently considered as an isolate into the species MeMV (Brown et al. 2015). Although MeMV seems to be one of the most frequent tomato begomovirus in Venezuela, little is known about its molecular diversity in the country. Hence, the present study aimed to estimate the genetic variations among MeMV isolates from tomato samples during different growing seasons and several Venezuelan states.

Twenty tomato plants, previously identified as positives to MeMV (Geraud-Pouey et al. 2015), were selected for molecular analyses. In addition, 70 samples of weeds, exhibiting virus-like symptoms, were also included for molecular detection of MeMV in this work. The collected weeds were as follows: Cucumis anguria $(n=8)$, Solanum pimpinellifolium $(n=8)$, Solanum amaricanun $(n=7)$, Heliotropium sp. $(n=6)$, Cucumis dipsaceus $(n=6)$, Cucumis melo var. agrestis $(n=5)$, Solanum hirtum $(n=4)$, Merremia sp. $(n=4)$, Sida agregata $(n=4)$ Malva sp. $(n=4)$, Ipomoea sp. $(n=3)$, Amaranthus sp. $(n=3)$, Datura stramonium $(n=2)$, Solanum sisymbriifolium $(n=1)$, Bidens squarrosa $(n=1)$, Solanum chilense $(n=1)$, Desmodium sp. $(n=1)$, Jussieua longifolia $(n=1)$, Tribulus cistoides $(n=1)$.

Total DNA extractions from leaf samples were performed according to Gilbertson et al. (1991). MeMV DNA was 
amplified by PCR using universal primers PAL1v1978 and PAR1c715 for begomoviruses (Rojas et al. 1993), which amplify the common region and part of the genes AV1 and AC1. This genomic region has been previously used to estimate genetic diversity of other begomoviruses from the New World (Nava et al. 2006; Sánchez-Campos et al. 2013; Geraud-Pouey et al. 2015). PCR amplicons were sequenced in both directions using an ABI-3130 genetic analyzer. Nucleotide sequence alignments of MeMV isolates were carried out using MUSCLE (Edgar 2004). Pairwise sequence comparisons were performed with Sequence Demarcation Tool (SDT) v.1.0 software (Muhire et al. 2014). The nucleotide alignment generated by MUSCLE was also used to evaluate potential recombination events using Recombination Detection Program 4 (RDP4) (Martin et al. 2015). For phylogenetic analysis, General Time Reversible plus Gamma was selected as the best model of nucleotide substitution using Modeltest (Posada and Crandall 1998) implemented online as FindModel (http://www.hiv.lanl.gov/cgi-bin/findmodel/ findmodel.cgi). MEGA 6 (Tamura et al. 2013) was used to build a phylogenetic tree with Maximum likelihood method (500 bootstrap replicates).

PCR assays, based on MeMV specific primers, confirmed the viral incidence in the 20 tomato samples, while no evidence of MeMV was found in the weed samples analysed. Afterwards, the expected PCR products ( 1300 bp), using the primers PAL1v1978 and PAR1c715, were obtained and sequenced from the 20 tomato samples. After sequence trimming, a useful 1012-bp fragment was retained to estimate the molecular variability of MeMV (GenBank accession numbers KT693164 to KT693183).

Nucleotide identity (NI) among MeMV isolates from Central America and Venezuela ranged between 90.4 and $100 \%$, whereas NI among Venezuelan isolates was 91.4$100 \%$. Similar ranges of genetic variability have been also reported for other begomoviruses infecting tomato in Latin America (Sánchez-Campos et al. 2013; Geraud-Pouey et al. 2015). Further analyses of pairwise identity were also

VE05-259[KT693171]
VE06-452[KT693173]
VE06-460[KT693174]
VE07-1073[KT693175]
VE09-1748[KT693181]
VE09-1749[KT693182]
VE09-1750[KT693183]
MeMV-Belize[EU709525]
MeMV-St.Kitts\&Nevis[GU320575]
MeMV-Belize[EU709522]
MeMV-Belize[EU709521]
MeMV-Puerto_Rico[DQ644558]
MeMV-Puerto_Rico[DQ644557]
MeMV-Puerto_Rico[AF068636]
VE08-1208[KT693176]
VE08-1209[KT693177]
VE09-1498[KT693180]
MeMV-Venezuela[AY508991]
VE09-1304[KT693178]
VE09-1307[KT693179]
VE04-140[KT693164]
VE04-141[KT693165]
VE04-153[KT693166]
VE05-240[KT693168]
VE05-252[KT693169]
VE05-254[KT693170]
VE05-328[KT693172]
VE05-239[KT693167]
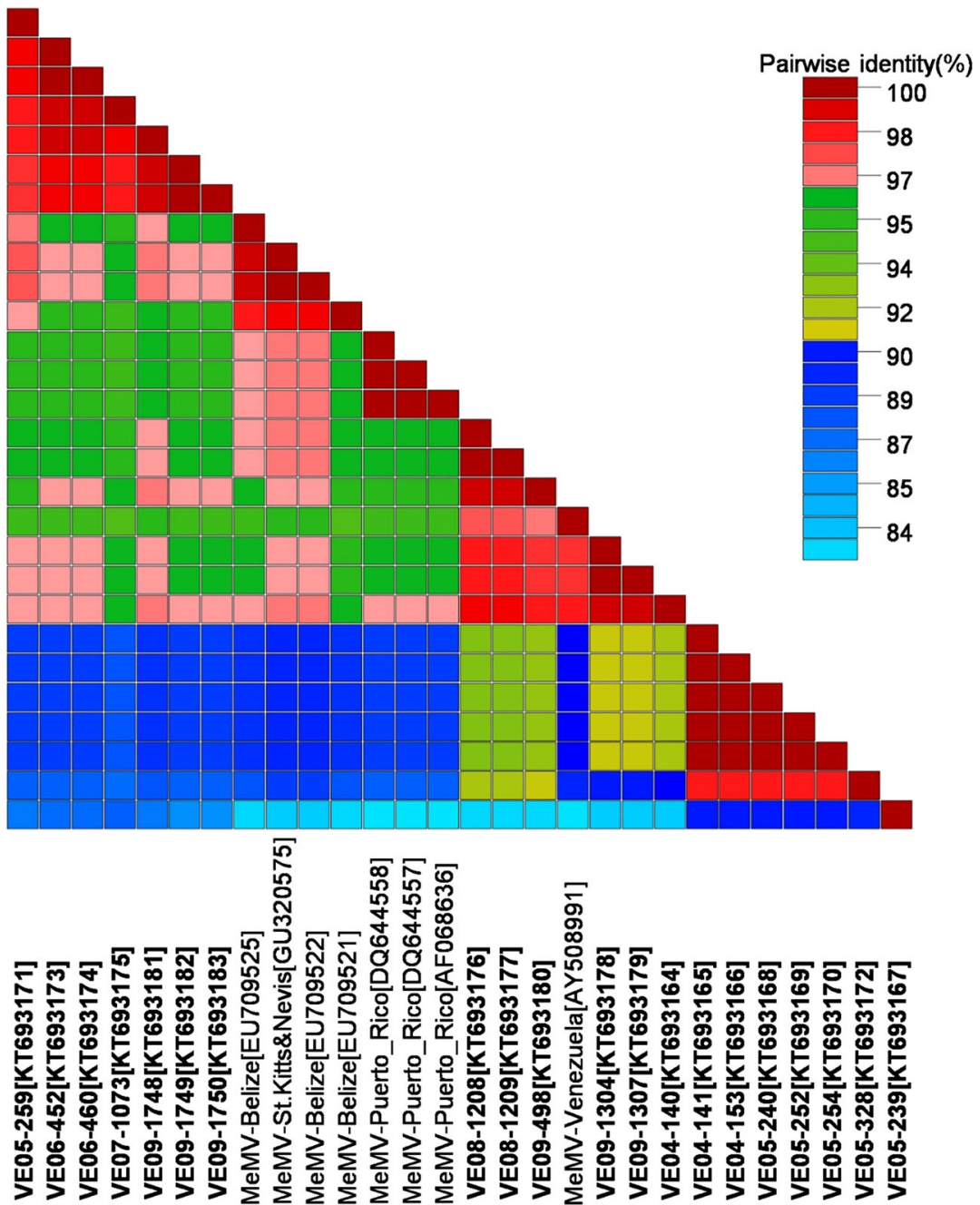

Fig. 1 Pairwise sequence identity analysis based on 185 amino acid sequence from the N-terminal region of Replication associated protein of MeMV isolates. In bold, Venezuelan isolates including their GenBank accession numbers within brackets 
performed using the partial amino acid (aa) sequence deduced from the N-terminal region of Replication associated protein (185 aa) which is code by AC1 gene. The most divergent isolates were VE04-141, VE05-153, VE05-328 from Trujillo state and VE05-239, VE05-240, VE05-252, VE05-254 from Barinas state, displaying $<94 \%$ of amino acid identity (AAI) with all studied isolates. The other Venezuelan isolates displayed AAI $>94.5 \%$ between them, as well as with isolates from Central America (Fig. 1). Either NI or AAI analyses showed that isolates from Central America were less divergent than Venezuelan isolates, regardless of the fact that Central America isolates were reported infecting several hosts (hot pepper, sweet pepper, Euphorbia heterophylla and Merremia spp.) (Brown et al. 2001; McLaughlin et al. 2008; He and Brown 2011). Certainly, more isolates from Central America are required to perform compelling genetic analyses because only six isolates were available in GenBank, at the time of this study was performed.
Phylogenetic relationships found in this work revealed two major clusters of MeMV (Fig. 2). On one hand, the cluster 1 included isolates from Belize, Puerto Rico, Saint Kitts and Nevis and Venezuela (93-100\% NI). On the other hand, the cluster 2 was only integrated by Venezuelan isolates (97.1$100 \%$ NI). Analyses also indicated that the diversity pattern of Venezuelan isolates was not associated with the site of collection (Fig. 2). This result could be expected due to the traffic of tomato seedlings across the country as was previously observed for Potato yellow mosaic virus (Nava et al. 2006; Chirinos et al. 2014; Geraud-Pouey et al. 2015). According to our results MeMV has a relative high genetic diversity in Venezuela compared to other begomoviruses widespread in the country, like Melon chlorotic mosaic virus (MeCMV), which has a low genetic diversity (NI $>97 \%$ ), even when analysing the full DNA-A component (Romay et al. 2015).

Recombination events involving MeMV have been found in a new begomovirus species, Jacquemontia yellow mosaic

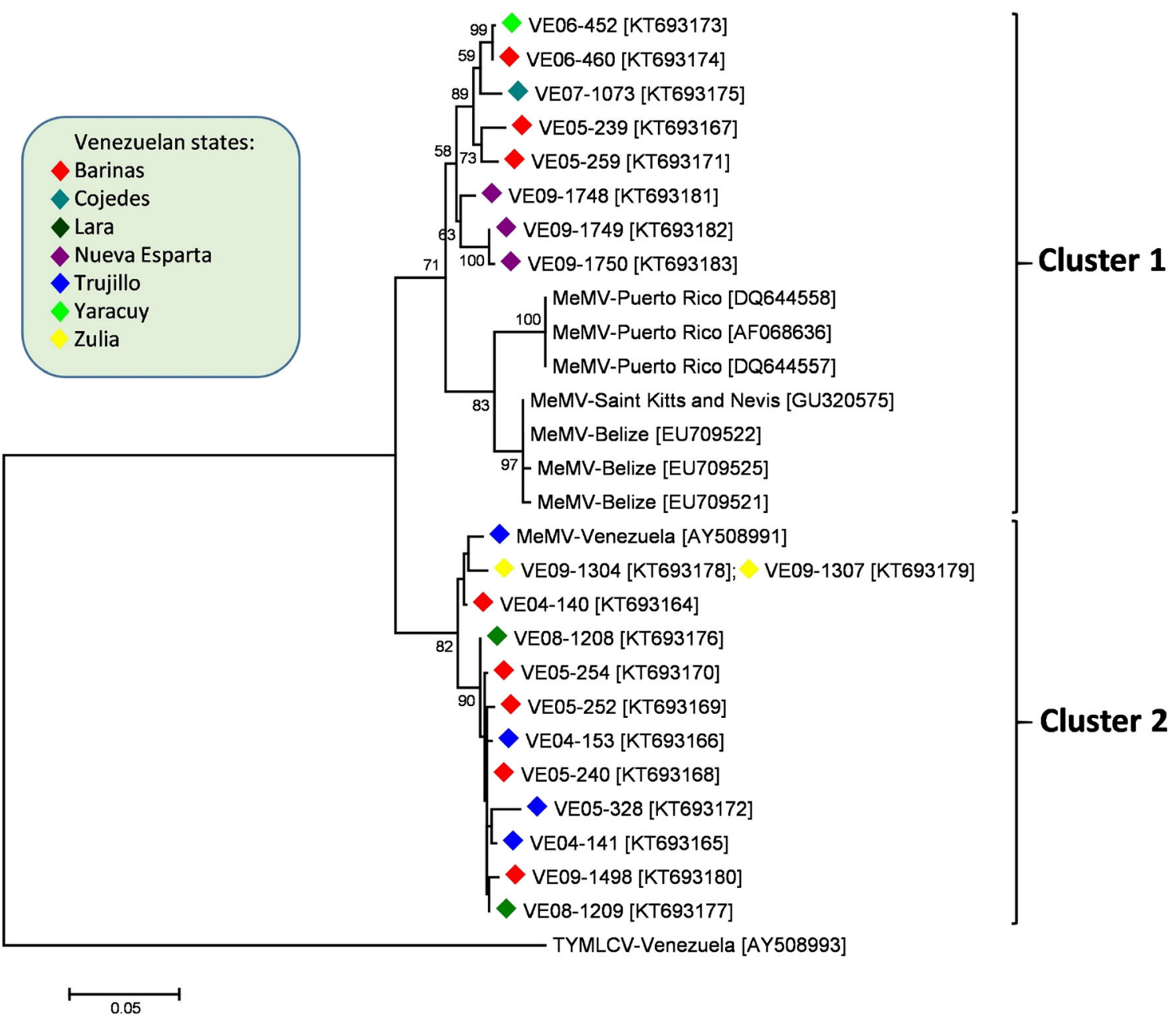

Fig. 2 Phylogenetic relationships of Venezuelan MeMV isolates from tomato fields and 8 from Caribbean basin countries. Sequences are identified with their GenBank accession numbers and those recovered from GenBank are also identified with their geographic origin. The phylogenetic tree was built based on Maximum likelihood method.
Bootstrap values (500 iterations) above $60 \%$ are indicated for each node. Tomato yellow margin leaf curl virus (TYMLCV) was included as outgroup. Samples in the same branch are identical. The green box indicates the colour key for the Venezuelan states where MeMV isolates were found 
virus (JacYMV), infecting the weed Jacquemontia sp. (Convulvolaceae) from Venezuela (Fiallo-Olivé et al. 2014). This finding along with the results presented in this work suggest a complex dynamic of viral diseases involving cultivated plants, weeds, begomoviruses and their vector, the polyphagous whitefly Bemisia tabaci. The latter one is widespread across the country and it has been associated with severe begomovirus outbreaks (Romay et al. 2010, 2011, 2014). Finally, although this study revealed an important extent of genetic diversity for Venezuela MeMV isolates, further studies leading to full-length sequencing of MeMV isolates are required to confirm their taxonomical status as strains or even new species. Moreover, whole genome sequencing of MeMV isolates may be useful to evaluate new recombination events associated with MeMV and further implications for epidemiologic risks.

Acknowledgments We thank Annika Gillis for critical reading of the manuscript. This research was supported by project FONACIT-G2000001610 and project 20070071 from Cuba-Venezuela Cooperation Agreement and project G-2000001610 from the Venezuelan Ministry of Higher Education, Science and Technology.

\section{References}

Brown JK, Idris AM, Torres-Jerez I, Banks GK, Wyatt SD (2001) The core region of the coat protein gene is highly useful for establishing the provisional identification and classification of begomoviruses. Arch Virol 146:1581-1598

Brown JK, Zerbini FM, Navas-Castillo J, Moriones E, Ramos-Sobrinho R, Silva JC, Fiallo-Olivé E, Briddon RW, Hernández-Zepeda C, Idris A, Malathi VG, Martin DP, Rivera-Bustamante R, Ueda S, Varsani A (2015) Revision of Begomovirus taxonomy based on pairwise sequence comparisons. Arch Virol 160(6):1593-1619

Chirinos DT, Geraud-Pouey F (2011) El manejo de plagas agrícolas en Venezuela. Análisis y reflexiones sobre algunos casos Interciencia 36:192-199

Chirinos DT, Geraud-Pouey F, Romay G, Fernández C, Bastidas L, Flores L, Güerere P (2014) Infección en begomovirus en plantas de tomate propagandas bajo diferentes condiciones de protección física de semilleros. Bioagro 26:57-62

Edgar RC (2004) MUSCLE: a multiple sequence alignment method with reduced time and space complexity. BMC Bioinform 5:1-19

Fiallo-Olivé E, Chirinos DT, Geraud-Pouey F, Moriones E, NavasCastillo J (2014) Complete genome sequence of Jacquemontia yellow mosaic virus, a novel begomovirus from Venezuela related to other New World bipartite begomoviruses infecting Convolvulaceae. Arch Virol 159:1857-1860
Geraud-Pouey CDT, Galindo-Castro I, Franco MA, Santana MA, Gillis A, Romay G (2015) Occurrence of six begomoviruses infecting tomato fields in Venezuela and genetic characterization of Potato yellow mosaic virus isolates. J Phytopathol. doi:10.1111/jph.12445

Gilbertson RL, Rojas MR, Russell DR, Maxwell DP (1991) Use of the asymmetric polymerase chain reaction and DNA sequencing to determine genetic variability of bean golden mosaic geminivirus in the Dominican Republic. J GenVirol 72:2843-2848

He Z, Brown JK (2011) First demonstration of infectivity in Nicotiana benthamiana using infectious clones of two monopartite begomoviruses, Sweet potato golden vein and Sweet potato leaf curl, and the bipartite Merremia mosaic virus, isolated from Merremia species in Puerto Rico. Phytopathology 101:S277

Martin DP, Murrell B, Golden M, Khoosa A, Muhire B (2015) RDP4: Detection and analysis of recombination patterns in virus genomes. Virus Evol. doi:10.1093/ve/vev003

McLaughlin PD, McLaughlin WA, Maxwell DP, Roye ME (2008) Identification of Begomoviruses infecting crops and weeds in Belize. Plant Virus 2:58-63

Muhire BM, Varsani A, Martin DP (2014) SDT: a virus classification tool based on pairwise sequence alignment and identity calculation. PLoS One 9:e108277

Nava AR, Patte CP, Hiebert E, Polston JE (2006) Detection and variability of Begomoviruses in tomato from the Andean States of Venezuela. Plant Dis 90:61-66

Rojas MA, Gilbertson RL, Russell DR, Maxwell DP (1993) Use of degenerate primers in the polymerase chain reaction to detect whiteflytransmitted geminiviruses. Plant Dis 77:340-347

Romay G, Geraud-Pouey F, Chirinos DT, Morales F, Herrera E, Fernández C, Martínez AK (2010) Transmission of tomato Venezuela virus by Bemisia tabaci (Gennadius) (Hemiptera: Aleyrodidae), in Maracaibo, Venezuela. Neotrop Entomol 39:266274

Romay G, Geraud-Pouey F, Chirinos DT, Santana MA, Galindo-Castro I, Márquez LM (2011) Microsatellites reveal widespread predominance of an invasive over an indigenous Bemisia tabaci (Gennadius) in Venezuela. Phytoparasitica 39:419-428

Romay G, Lecoq H, Geraud-Pouey F, Chirinos DT, Desbiez C (2014) Current status of cucurbit viruses in Venezuela and characterization of Venezuelan isolates of Zucchini yellow mosaic virus. Plant Pathol 63:78-87

Romay G, Lecoq H, Desbiez C (2015) Melon chlorotic mosaic virus and associated alphasatellite from Venezuela: genetic variation and sap transmission of a begomovirus-satellite complex. Plant Pathol 64: $1224-1234$

Sánchez-Campos S, Martínez-Ayala A, Márquez-Martín B, AragónCaballero L, Navas-Castillo J, Moriones E (2013) Fulfilling Koch's postulates confirms the monopartite nature of tomato leaf deformation virus: a begomovirus native to the New World. Virus Res 173:286-293

Tamura K, Stecher G, Peterson D, Filipski A, Kumar S (2013) MEGA6: molecular evolutionary genetics analysis version 6.0. Mol Biol Evol 30:2725-2729 